УДК 7.035(48)2

ББК 85.14

DOI:10.18688/aa155-7-73

Giovanna Perini Folesani

\title{
Sir Joshua Reynolds and Classical Art: Notes on his Mythological Paintings, Most Notably The Infant Hercules for Empress Catherine II $^{1}$
}

On February $20^{\text {th }}, 1786$ writing to Charles Manners, the $4^{\text {th }}$ Duke of Rutland, one of his major patrons at the time, Sir Joshua boasted of a new commission:

"I have received a commission from the Empress of Russia to paint a historical picture for her, the size, the subject and everything else left to me [...] The subject I have fixed on [...] is Hercules strangling the serpents in the cradle, as described by Pindar, of which there is a very good translation by Cowley" [19, p. 158, letter n. 150 $]^{2}$.

When dispatching the picture three years later, he wrote to Prince Grigory Alexandrovich Potemkin, a favourite and counsellor of the Empress, explaining his selection of its subject matter (Hercules in his cradle strangling serpents described by Pindar in his $1^{\text {st }}$ Nemeian ode) as a distant allusion to the valour of the young Russian Empire [11; 35, pp. 312-313, n. 140; 25, I, pp. 539-540, n. 2094] $]^{3}$. Obtained via the British envoy in St. Petersburg, John Joshua Proby, first Earl of Carysfort (one of Sir Joshua's most assiduous friends, a keen collector of his subject pictures and a sitter for his portraits since childhood), this highly prestigious commission from Catherine II, possibly favoured by Princess Ekaterina Dashkova, marked a momentous event not only in Sir Joshua's long career approaching its end, but also in the Anglo-Russian relationships [11, pp. 8-9; 37, p. 206]. Its political significance was obvious to everybody in England, even to the supercilious intellectuals ready to criticize as "nonsensical" the very choice of its subject. Horace Walpole, Hannah More and, before them, the anonymous Grub Street hack writing for the English Chronicler, while damning the classical theme as "an old threadbare tale", agreed that instead Reynolds should have chosen a subject related to either Russian or English history, or both, such as Peter the Great in the dockyard at Deptford working as a shipwright, or some episode celebrating the ruling Czarina, born Sophie von Anhalt-Zerbst, as German as the Electoral House of Hannover ruling the British Isles since 1714 [48, pp. 11-43]. Sir Joshua himself

The powerpoint shown during the conference can be seen in my website on Researchgate. I am grateful to my University colleague, Prof. Maria Elisa Micheli, an archaeologist, for reading and commenting an earlier draft of the present paper.

See also [11, pp. 125-127, n. 73] and [25, I, pp. 539-540, n. 2094], where the English translation of Pindar actually used by Reynolds (West, rather than Cowley) is also discussed.

For Reynolds's letter in French to Prince Potemkin, see [19, pp. 195-197, n. 188]: it is not an autograph and is obviously a translation, for Reynolds had no French. 
had originally thought of depicting Queen Elizabeth inspecting her troops at Tilbury - a British parallel to the Czarina's modern predicaments.

This kind of historical narrative was to become very popular in the course of the $19^{\text {th }}$ century, both in UK and in Russia. The 1791 set of large pictures by Andreas Caspar Huhne celebrating the Russian victories against the Turks may illustrate what Walpole and his likes had on their minds. On the contrary, the image of Czar Peter I at Deptford, far from "complimenting" both countries, would have lowered the status of the Russian Czar to the only advantage of Great Britain, a thought that must have struck Reynolds's very sensitive mind, so versed in what Richard Wendorf has termed "complacency" or "the art of pleasing" [46, pp. 11-59]. This, together with his outspoken preference for classical subject-matters and outfits, must have prompted him to fall back on timehonoured classical mythology as more fit to the occasion [38, pp. 127-129, 134-135, 136-141]. In case, his mistake was to believe that the Infant Hercules was an original subject-matter.

The allegorical praise of a ruler's or a nation's strength in Herculean terms was common enough in European celebrative medals, as is shown by the medals celebrating Czar Peter the Great for his military deeds. Occasionally this commonplace had been applied even to Catherine II, although comparisons with Pallas were probably deemed more appropriate to a female sovereign, as in the 1770 medal celebrating her victories over the Turks or in the 1774 gold snuff-box by Jean Pierre Ador. Even official portraiture implied an equation with this Goddess, just as Peter the Great's son when still a child had been portrayed as a young Apollo (rather than Cupid) darting arrows around.

In 1783, when the United States of America was barely 7 years old, France issued a gold medal celebrating the Northern American British colonies turning into a brandnew sovereign state thanks to her vital assistance. Benjamin Franklin conceived its invention. The reverse shows France disguised as Pallas protecting the newly born nation (in the guise of the infant Hercules fighting for life against two snakes) by interposing her shield decorated with emblematic lilies to fend off the simultaneous attack of a rabid maneless lion or leopard representing Great Britain [23, pp. 86-90; 34, pp. 141-194 and ill. 6.1, p. 141; 44, ill. 19.5 and chapter XIX]. Not surprisingly, in the United States half a century later, in 1841, the recollection of French aid had entirely faded away. When Horatio Greenough conceived his monument to George Washington in terms of a classical god or hero sitting on a throne, on the right side of the seat he carved the image of the infant Hercules strangling a snake unaided, literally singlehanded [49, pp. 420-421].

Much before then, in 1688, the infant Hercules had been ominously used in UK to represent the predicament of the newly-born James Prince of Wales, the son and heir of James II, the ruling Catholic Stuart King. Unfortunately the new James did not possess the stamina of the Greek hero and was never to sit on his throne, because of the Glorious Revolution sparked by his very birth [8, p. 126; 14, p. 63]. Archduke Joseph of Austria was luckier. The medal struck to celebrate his birth in 1741, similarly portraying him as the infant Hercules on its reverse, paved his way to the throne, where he sat as Joseph II even 
before his mother Maria Theresia's death ${ }^{4}$ - possibly because in his case the snakes were mere figments of poetical imagination ${ }^{5}$.

This early feat showing the superhuman strength and courage of Hercules when still a baby had been fairly common on the reverses of Greek silver and bronze coins, from the $5^{\text {th }}$ century $\mathrm{BC}$ through to the $3^{\text {rd }}$, only to be taken up again in the eastern provinces of Imperial Rome, especially under Commodus, Caracalla and Geta in the $2^{\text {nd }}$ and early $3^{\text {rd }}$ centuries AD [22, IV.1, p. 829, nn. 1619, 1621, 1623 and 1630-1632; p. 830, n. 1633; p. 831, nn. 1663-1664 and IV.2, pl. 553, nn. 1619, 1621, 1623; pl. 554, n. 1633; pl. 554 , nn. 1630-1632; pl. 556, nn. $1663-1664 ; 43$, p. 354$]^{6}$. As is well known, Commodus was the first Roman emperor to be identified with and adored as Hercules. Statues portraying him in this disguise, and even in his infancy strangling serpents, were soon made, associating the time-honoured Greek myth with modern Imperial implications [16, pp. 188-189, n. 25; 22, IV.1, p. 829, n. 1626]. Hence this iconographic theme reached both Byzantium and the most Northern areas of the Roman Empire, like Celtic Britain, where the head in profile of Hercules wearing the skin of the Nemeian lion on the obverse is generally matched, on the reverse, by the emblematic eagle of his father Zeus holding snakes in his claws? ${ }^{7}$. This is obviously a clever variation on the outcome of the same episode stemming from the jealousy and revenge of Hera, the god's betrayed wife, after whom the child was preposterously named (Herakles, Herakliskos) ${ }^{8}$.

Surely Reynolds did not know each and every such medals and coins, but he may well have seen some reproduced in the several illustrated numismatic and especially antique gem catalogues printed all over Europe in the $16^{\text {th }}, 17^{\text {th }}$ and $18^{\text {th }}$ centuries, some of which he could peruse in his own library or at the Royal Academy, ${ }^{9}$ where he could also study a cast after an antique Herakliskos, detectable in one of Zoffany's pictures of the Academy rooms [45, p. 252, ill. 204; detail on p. 255, ill. 205]. More to the point, Reynolds could find depictions of the infant Hercules strangling serpents in both modern and antique paintings and sculptures, as well as in prints. The variety of inventions, also in relation to the child's attitude, is striking, but none impressed Reynolds enough to urge him to direct borrowing [27, p. 216]. ${ }^{10}$ His belaboured

\footnotetext{
4 ACR Auctions, e-auction 23, lot 1245, Medaglie estere Arciduca Giuseppe d'Austria. Available at: www.artcoinsroma.it (Accessed January 20, 2015).

The first modern medal of a ruler exploiting this subject-matter is possibly the reverse of Cosmè Tura's medal of Alfonso d'Este (1477) in the Ashmolean Museum, Oxford. Tura C. Alfonso d'Este in The Web Gallery of Art. Available at: http://wga.hu/html_m/t/tura/various/zmedal2.html (Accessed January 20, 2015). 6 The Labours of Hercules. Ancientcoinage.org: Ancient Numismatic Mythology website. Available at: http://ancientcoinage.org/the-labors-of-hercules.html [lot 1570] (Accessed January 20, 2015).

7 Catalogue. Downies.com: Australia's oldest Numismatic Auction House website. Available at: http://downies.com/aca/Auction312/Catalogue_053.html (Accessed January 20, 2015).

8 Herakles-Hercules. Provincial-romans.com: Numismatic website. Available at: provincial-romans. com/provincial/Themes/HeraklesHercules.htm (Accessed January 20, 2015).

$9 \quad$ For a selection of antique gems, see [22, IV.1, p. 828, nn. 1606-1610 and IV.2, pl. 552, nn. 16061607; pl. 553, nn. 1608-1610]. For antique gem catalogues see [12, III, pp. 402-435].

10 "Reynolds's visual quotations were less blatant than in his earlier works". Among earlier modern sources he could draw on, there are works by Annibale Carracci, Alessandro Algardi (van der Gucht's etching in [28, p. 317] is a copy after it), Ercole Ferrata, Pieter van der Werff (whose invention is fairly close to Algardi's), Bernardino Mei and Pompeo Batoni, as well as drawings by Giulio Romano - engraved by Agostino Veneziano and used by Leonard Limosin in a round enamel - by a Parmigianino follower, by Prospero Fontana and by Lorenzo Loli (etching). Others are discussed more extensively in the text.
} 
invention for the baby protagonist, documented by at least four extant sketches [35, p. 313], ${ }^{11}$ has met with long-lasting popularity. It is based on the reworking of an antique model seen in 1752, the infant Hercules [26, pp. 96-97, n. 63], since 1589 on show in the Tribuna of the Uffizi, where Zoffany was later to record it and Flaxman to study it, just as Alessandro Allori had done in the late $16^{\text {th }}$ century. ${ }^{12}$ The popularity of this antique statue through the ages is proven by a number of Renaissance bronze replicas, as well as by its steady, albeit clumsy reproductions in Greek and Roman imperial coins, such as Caracalla's. The Florentine statue differs from the Hermitage version because of the stronger emphasis placed on the verticality of its triangular composition, marked by the raised right arm of the child, like in the celebrated Laokoon. This extended arm (a modern restoration, like in the Laokoon's) is the one feature retained by Reynolds from this model, as shown in his two sketches engraved in the $19^{\text {th }}$ century, including the amazing pen sketch in the Herschel Album published by Luke Herrmann [18, p. 652, ill. 6]. Neither these sketches, nor the final picture have got anything to do with the German woodcut by Albrecht Altdorfer once part of Reynolds's collection of prints, quoted by Leslie and Taylor as the source for Sir Joshua's Hercules [21, II, pp. 482-484]. In fact, Altdorfer's print derives from the antique statue in the Musei Capitolini, Rome [22, IV.1, p. 830, n. 1634; IV.2, pl. 554, n. 1634] ${ }^{13}$.

The rest of the child's body is taken from a modern work Reynolds had often put to use in his earlier subject-pictures, namely Carlo Maratta's The Christchild adored by Angels, which Nathaniel Hone, in his libellous picture The Conjuror (1775), was the first to expose as the source for Reynolds's Ideal portrait of Samuel Johnson as a child [32, pp. 348-350 and ills. 9798; 25, I, p. 541, n. 2097], as well as for his Infant Jupiter (1774), destroyed in the 1816 fire of Belvoir Castle, the country house of the Duke of Rutland [25, I, pp. 541-542, n. 2098]. Subsequently this pattern was adapted also to his Puck for Boydell's Shakespeare Library [25, I, p. 557, n. 2142], virtually contemporary to the Infant Hercules. As for Hercules's frightened brother Iphicles, Reynolds may have put to use some anonymous, highly finished drawings of puttoes in his collection, one drawn after Duquesnoy and another one by an Italian classicist Baroque draughtsman recently misidentified as "Guercino". ${ }^{14}$ Like in most of his subject pictures, Reynolds started building up the general framework of his composition only after working on the picture's seminal core, i.e. the single figure of its protagonist. ${ }^{15}$ Everything else has been built around it afterwards.

11 See in particular British Museum, Dept of Prints and Drawings, 1887.0301.16 and 17, for which see $[9$, p. 28, n. 95].

${ }_{12}$ For Flaxman, see [1787 sketchbook at the Yale Center for British Art, acc. n. B1975-3-468 (27)], for Zoffany [45, pp. 281-301, esp. 286] and [30, esp. p. 14 and final table, n. 51]. For Reynolds's visit at the Uffizi, see [36, pp. 453-454, 460-462]. The Warburg Institute Iconographic Database - Gods \& Myths-HerculesMyths: Infancy \&Childhood, Infant Hercules Strangling Serpents, records 12517, 13367, 13390. Available

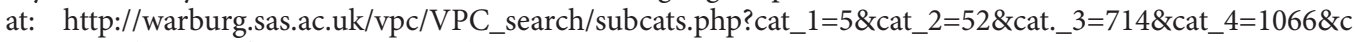
at_5=815 (Accessed January 20, 2015).

${ }_{13}$ http://warburg.sas.ac.uk/vpc/VPC_search/subcatsphp?cat_1=5\&cat_2=52\&cat._3=714\& cat_4=1066\&cat_5 $=815$, record 13311

${ }_{14} \quad$ Cf. British Museum, Dept. of Prints and Drawings, accession nos. 1872.1012.3380 and 1911.0517.22 (the latter reproduced in $[41$, p. 104, ill. 23] )

15 See supra, note 11 and [37, pp. 211-212]. For oil sketches of the infant (both preparatory and copies; see [25, I, pp. 540-541, nn. 2094 a-b, 2095 a-h, 2096]. 
Another striking feature of this picture is the rolling cradle, with its prominent neoclassical decoration consisting of an anthemium (small palm leaf) and a row of waves above. While the general shape of the rolling cradle is the only element retained from Reynolds's earlier studies for his infant Hercules, its decoration derives from fragments of Roman friezes such as the ones in the Trajan Forum [1, esp. pp. 24, 34], which inspired most contemporary academic pattern-books for ornaments [3, reproduced in 2 and discussed in 39 and 10]. Not surprisingly, it can be found in a number of Greek vases depicting the same myth. A pen drawing by Leonello Spada is the only known modern depiction showing some vague similarity to Reynolds's invention ${ }^{16}$. The decoration of the cradle is the one feature retained by the anonymous early $19^{\text {th }}$ century British illustrator of the Dictionary of Polite Literature, or, Fabulous History of the Heathen Gods (1804), whose infant Hercules stems directly from the Uffizi model [47, II, pl. unnumbered ad vocem "Hercules"].

As for the figure of Tiresias, British art historians have often noticed the similarity of his attitude to the one of Samuel Johnson during one of his occasional seizures as portrayed by Reynolds (1769) [37, p. 216; 25, I, p. 540], but have spent no words on his curious attire. It does not fit either Greek or Roman standards, showing Oriental influences. In fact it harks back to the so-called Sardanapallos type of Dionysos, which Reynolds may have seen either in well-known antique bas-reliefs, reproduced in prints since the previous century, or in herms and statues, often damaged and therefore without arms, excavated in the areas around Rome and Naples at various times [22, III.1, pp. 431-432, n. 89] ${ }^{17}$. Reynolds was aware of the differences between classical and oriental garments. When painting the cartoons of the seven virtues for the chapel-window in New College, Oxford, he fell back on generic timeless garments, but in the case of Fortitude, resembling a Pallas-Minerva, it has been remarked that Reynolds adopted the pose and attire of the so-called Cesi Juno or Hera, of which copies were available in prints [35, pp. 290-291, nn. 119-120, col. pl. 146 and ill. 81; 25, I, p. 549, n. 2114; 16, pp. 242-243, n. 51; 7, pp. 55-56, n. 8], although he may have used also his studies after recently unearthed colossal statues preserved in his Plymouth City Museum sketchbook. ${ }^{18}$

Little attention has been paid to the figure of Hera, wearing her usual diadem and hovering above the scene accompanied by her peacocks, her gestures showing disappointment at the unforeseen turn of events, when Hercules both literally and unexpectedly gets the upper hand $^{19}$. It has been noted how her features seem to match those of Sarah Siddons, a famous actress often portrayed by Reynolds - an opinion recently rejected [37, p. 337, note 34], but nevertheless tenable $[11, \text { pp. } 12,6]^{20}$. The presence of this Goddess, albeit appropriate, is comparatively rare. Among the few examples to be cited is a beautiful Renaissance medal

\footnotetext{
$16 \quad$ See note 12. The Warburg Institute Iconographic Database, record 13324.

17 Although the Vatican statue was unearthed as late as 1761 (see [42, pp. 50-53, n. 3]), it was soon made available in prints. Other well-known examples in reliefs are discussed in [7, pp. 122-124, nn. 90-91]. For comparable types see also [22, III. 2, pl. 303, n. 94a; pl. 302, n. 88; or pl. 431, n. 38, as well as pl. 404, nn. 856 and 858]. In turn, this type has historical connections with the portrait of the philosopher-magician Apollonius Tianeus, an almost legendary character that fits admirably those of both Tiresias and Dr. Johnson. ${ }_{18}$ Plymouth City Museum sketchbook (formerly Copland-Griffiths' larger sketchbook, abbreviated CG/61), fols. 71v and 72v. Cf. [4, pp. 52-54].

19 For standard images of Hera wearing a diadem, see [6, figs. 160, 164, 166, 761-762].

20 For Sarah Siddons' countenance and her major portraits, see [5].
} 
by l'Antico, where two female figures beneath (most likely Alcmena and a maid) wave their arms in a curious mixture of surprise, heedless fright, despair, astonishment and wonder ${ }^{21}$ [17, p. 273, fig. 48]. In a way, Alcmena's pose in Sir Joshua's picture is not so different from theirs. In fact it recycles the figure of Anna from Sir Joshua's Death of Dido of 1780 [35, pp. 294-295, n. $123 ; 25$, I, pp. 526-528, n. 2065]. In turn, this derives from a stereotype in Italian mannerist Depositions, from Daniele da Volterra through to Titian and Palma, although some British scholars refer the motif to Poussin, a painter that Reynolds did not admire ${ }^{22}$.

It is not surprising if the marginal figure of Alcmena's husband, King Amphitrion, is repeated in reverse in another history painting by Reynolds now at the Hermitage, The Continence of Scipio, where he features as the protagonist [25, I, p. 520, n. 2047]. Commissioned by the same John Joshua Proby on behalf of Prince Potemkin as a virtual, ideal pendant or complement to the imperial commission, this picture accompanied the infant Hercules on its journey to Russia in 1789 and was eventually reunited to it when the Prince's heirs sold their picture to The Hermitage. The style of Prince Potemkin's picture has often been misunderstood as Parmigianinesque. ${ }^{23}$ In case, its colours and composition are reminiscent of the style of one of Reynolds's favourite Italian painters, the Bolognese Ludovico Carracci. Coherently enough, his Scipio's rembrandtesque features seem to hark back to a picture of the same subject now in New York by one Ludovico's late followers, Giuseppe Maria Crespi, an unobvious Bolognese admirer of Rembrandt's [29, pp. 284-285, entry and ill. n. 178] $]^{24}$. Conversely, the Infant Hercules is entirely Reynoldsian in style, although its colours and the figure of Amphitrion are

$21 \quad$ The Warburg Institute Iconographic Database, record 13367.

22 The intertext for Dido has been identified with either Giulio Romano's Psyche in Mantua or the classical statue of the so-called Cleopatra, or Ariadne, of which a number copies exist in Rome, Florence, Paris, St. Petersburg and elsewhere (see [20] and also [16, pp. 184-187, n. 24] and [7, pp. 113-114, n. 79, p. 98, n. 62]). In fact, the latter is the source for Giulio Romano's picture, which in turn is closer to Reynolds's invention. Its new geometrical emphasis on the composition of the figure is summarized in a British Museum red-chalk sketch which served also as a schematic grid for the invention of Reynolds's celebrated Venus and Cupid: see British Museum Prints and Drawings, accession number 1886.0609.35. In this case the same altered classical model is merged with the modern but obscure example of a "Sleeping Magdalen" by Livio Mehus, a Flemish-Florentine painter whose work Reynolds greatly admired (her loose garments are an afterthought addition and reworking to please Vittoria della Rovere, who preferred pious religious subjects to ancient goddesses in the raw: see [36, p. 156, note 369], with earlier literature). In any case, Reynolds's new interpretation of the ancient statue in the light of Giulio Romano's picture has also spurred a number of later elaborations and reworkings, especially by Fuseli. In a way also Reynolds's other hit in subject-pictures, the coquettish Venus (or Nymph) and Cupid composition also known as The Snake in the Grass (or Cupid Untying the Zone of Venus) comes from a clever adaptation of the same model, simply by lowering onto the girl's face the bent arm originally resting on the head of its original antique model [25, I, pp. 552-554, nn. 2125-2126 and 2128-2130]. A late, snakeless version of this picture is preserved at the Hermitage, having come to Russia at the same time as the Infant Hercules as a gift by John Joshua Proby to Prince Potemkin [25, I, p. 553, n. 2127]. Finally, also Cupid in Sir Joshua's Cupid and Psyche is conceived according to the same graphic pattern, albeit reversed and applied to the sleeping boy [25, I, p. 522-523, n. 2054].

${ }_{23}$ This was William Young Ottley's interpretation. He also claimed that Reynolds was angry at his remark, for he had stolen the invention from that painter: see [37, p. 227]. It is easier to assume that Reynolds was angry because Ottley had totally misinterpreted the painting's Italian visual sources.

$24 \quad$ Nothing in the known history of this picture, painted in the 1720s, enables us to state that it was known to Reynolds (whose interest in this painter is well known). All we can say is that two autograph versions of this picture are mentioned in contemporary literature, one in Bologna and the other one in Verona. Reynolds may have seen either, since he visited both cities. 
clearly affected by Rembrandt. In particular, the shape of Amphitrion's helmet, its shining gold and the deep dark shadow cast from its peak onto the king's brow and eyes are all elements easy enough to find in both Northern and Italian Rembrandtism, as well as in many Selfportraits by Rembrandt. Reynolds started experimenting with these effects of shadow towards the end of or soon after his Italian stay and continued in female portraiture to the end of his days [36, pp. 20-21, note 44].

As for the female servants attending the infant Hercules, so extraordinarily modern in attitudes and design, only the one in the forefront on the right has been discussed by British scholarship, claiming that its intertext is Michelangelo's Lybian Sybil from the Sistine ceiling [25, I, p. 540]. In fact, her sudden turning away is much closer to Raphaelesque patterns such as the figure on the forefront in the Transfiguration or its model in reverse, in the Expulsion of Heliodorus in the Vatican Stanze, later to be taken up by Poussin in his Sacrament of Communion from the Cassiano dal Pozzo series, acquired by the Duke of Rutland following the advice of Sir Joshua Reynolds and preserved in Belvoir Castle [50, p. 72, fig. 51 and 190-191, n. 110]. The other female servant to the left, rushing forward behind the dog in the foreground, is hard to see in most photos, partly because of the heavy craquelure, a result of Reynolds's peculiar technique. (As Reynolds told Northcote, "there were ten pictures under it, some better some worse" [33, II, pp. 214-219]). Her pose is more intelligible in prints, where her protruding, parallel arms clearly evoke the emotional gestures of the Mary rushing forward to assist the Virgin lying senseless at the foot of the cross, like in Barocci's Deposition in Perugia, a picture certainly seen and admired by Reynolds in Italy [36, pp. 92, 219-220]. Similar figures occur also in Poussin's paintings and elsewhere, but the main difference is that while in continental models the heads of the figures always look forward, in the same direction as their projected hands, arms and body, in Reynolds's picture the servant's head is turned sideways in a sudden, unnatural movement to check what is happening in the cradle from which she is fleeing in fright. Albeit original, this invention found no immediate followers. On comparable occasions even Fuseli preferred to simplify and standardize earlier continental topoi [e.g. 40, p. 53, fig. 7 and p. 94, n. 102].

Despite favourable critical reception by Barry, Fuseli and British journals and despite being reproduced by British engravers both before and after its shipment to Russia [35, p. 313; 37, pp. 218-222; 25, I, p. 540; 15, pp. 417, 427 and ill. 410, pp. 418-419] ${ }^{25}$, Reynolds's complex, ambitious picture had little impact on British and European high art (Ill. 111). Throughout two centuries and even across the Atlantic, its memory seems to have been kept alive mostly by popular satirical prints. This is probably fair, given that in fact its invention may have been sparked by one such low-genre visual source. Thomas Rowlandson's vignette depicting William Pitt as the infant Hercules strangling his rivals (Charles James Fox and Frederick, Lord North, disguised as snakes) predates Reynolds's picture by almost a couple of years, as it was issued in February 1784 [13, p. 115-116; 37, p. 217; 34, p. 186 and ill. 6.10; 27,

In 1845 Alfred Joseph Stothard struck a bronze medal for the Art Union of London with Reynolds's profile on the obverse and his baby Hercules on the reverse see: Stothard A. J. Joshua Reynolds. Victorianweb. org:Literature, history and culture in the age of Victoria web. Available at: http://victorianweb.org/sculpture/ medallists/stothard1.html (Accessed January 20, 2015). 
p. 160, ill. and entry n. 121 ${ }^{26}$. Both Fox and Lord North, as well as their families, were among Reynolds's earliest, more regular patrons and friends, therefore he must have known this print, so popular to be converted into a clumsy marble sculpture by an Italian, Pietro Pierantoni ${ }^{27}$ [record 13390; 24, pp. 235-236] ${ }^{28}$. Thus it might be inferred that the high-pitched celebration of a foreign ruler, while styled in learned and obsequious classical terms, was eventually sparked by contemporary British political satire.

Author: Giovanna Perini Folesani - Full Professor. University of Urbino "Carlo Bo", Palazzo Albani, Via Bramante, 17, 61029 Urbino, Italy. giovanna.perini@uniurb.it

Title: Sir Joshua Reynolds and Classical Art: Notes on his Mythological Paintings, Most Notably The Infant Hercules for Empress Catherine II.

Abstract. This essay explores and tries to identify and discuss all the visual sources tapped on by Reynolds to paint his Infant Hercules for Empress Catherine II, at the Hermitage in St Petersburg, as well as for The Continence of Scipio for Grigori Alexandrovich Potemkin, which was shipped together with the former and is nowadays exhibited in the same room at the Hermitage. Unlike the histories of their commissions, the deconstruction of their visual sources is almost entirely original. To implement his idea of presenting young Russia in the image of a mighty baby-hero from Classical mythology, Reynolds was looking for inspiration, and could find depictions of the infant Hercules strangling serpents in both modern and antique paintings and prints, as well as in coins and sculptures. His invention for the baby protagonist is based on the reworking of an antique model seen in 1752, the 'Infant Hercules', since 1589 on show in the Tribuna of the Uffizi. The popularity of this antique statue through the ages is proven by a number of Renaissance bronze replicas, as well as by its steady, albeit clumsy reproductions in Greek and Roman imperial coins, such as Caracalla's. Though less blatant than in his earlier works, Reynolds's visual quotations are to be found among earlier modern sources he could draw on, like the works by Annibale Carracci, Alessandro Algardi, Ercole Ferrata, Pieter van der Werff,++ etc. Special attention is drawn to Thomas Rowlandson's political satire of which Reynolds must have been also aware.

Keywords: Sir Joshua Reynolds; The Infant Hercules; The Continence of Scipio; visual sources; art patronage.

Название статьи. Сэр Джошуа Рейнолдс и античное искусство: заметки о живописи на мифологические сюжеты на примере картины «Младенец Геракл, удушающий змей», написанной по заказу Екатерины II.

Сведения об авторе. Джованна Перини Фолезани - профессор. Урбинский университет имени Карло Бо, Palazzo Albani, Via Bramante, 17, Урбино, Италия, 61029. giovanna.perini@uniurb.it

Аннотация. В статье рассматриваются и обсуждаются все варианты возможных источников и визуальных заимствований для написания Дж. Рейнолдсом картины «Младенец Геракл, удушающий змей», выполненной им по заказу Екатерины II, ныне хранящейся в Государственном Эрмитаже. Вторая картина, отправленная вместе с нею в Россию, - «Великодушие Сципиона Африканского» - была исполнена художником для светлейшего князя Григория Александровича Потемкина и сегодня экспонируется в Эрмитаже в том же зале. В отличие от хорошо известной истории заказа обеих картин, их искусствоведческий анализ в процессе поиска визуальных источников и одного, и другого произведения представляет собой совершенно оригинальное исследование. Выбор темы для картины, заказанной русской императрицей, был предоставлен художнику. Автор статьи касается политической подоплеки выбранного мифологического сюжета для этого заказа, указывая на мягкую аналогию между силой будущего героя Эллады и формирующейся мощью молодого российского государства. Для воплощения замысла в образах Рейнолдс черпал вдохновение и цитировал как новые живописные произведения и гравюры, так и античные скульптуры и штампы античных монет. К числу последних относятся, например, монеты Каракаллы, а среди скульптур наиболее известна античная статуя «Младенец Геракл», с 1589 г. экспонировавшаяся в Галерее Уффици и виденная художником в 1752 г. Визуальные заимствования Рейнолдса для екатерининского заказа не столь очевидны, как в его более ранних работах, однако автор уверенно указывает на произведения Аннибале Карраччи, Алессандро Альгарди, Эрколе Феррата, Питера ван дер Верффа и др. Особого внимания заслуживает политическая сатира Томаса Роулендсона, которая, без сомнения, также была известна Рейнолдсу.

Ключевые слова: сэр Джошуа Рейнолдс; «Младенец Геракл, удушающий змей»; «Великодушие Сципиона Африканского»; визуальный источник; покровительство искусству.

\footnotetext{
26 Mere chronology is enough to belie Mülller's assumption that Rowlandson draws from Reynolds's invention [31, p. 63]

$27 \quad$ See supra, note 11.

28 On Fox and Lord North, see [25, I, pp. 202-204, nn. 672-677, pp. 353, nn. 1344-1345] and [15, passim] and [35, pp. 185-186].
} 


\section{References}

1. Albertolli F. Fregi trovati negli scavi del Foro Traiano con altri esistenti in Roma ed in diverse città d'Italia. Milano, Bettoni Publ., 1824. 2 p. 1., 23 [i.e. 25] pl. (in Italian).

2. Albertolli G. I repertori di ornato. Cinisello Balsamo, Silvana Publ., 2002. 128 p (in Italian).

3. Albertolli G. Ornamenti diversi inventati, disegnati ed ornati. Milano, G. Albertolli Publ., 1782. 24 p. (in Italian).

4. Andreae B.; Anger K.; Granino M. G., et al. Museo Pio Clementino. Cortile ottagono Bildkatalog der Skulpturen des Vatikanischen Museums, vol. 2. Berlin - New York, Walter de Gruyter Publ., 1998, 422 p. (in German).

5. Asleson R. (ed.) A Passion for Performance, Sarah Siddons and her Portraitists. Los Angeles, The J. Paul Getty Museum Publ., 1999. 144 p.

6. Bieber M. Ancient Copies - Contributions to the History of Greek and Roman Art. New York, New York Press Publ., 1977. 362, xliv p.

7. Bober Ph. P.; Rubinstein R. O. Renaissance Artists and Antique Sculpture - A Handbook of Sources. London, Brepols Publ. 581 p.

8. Clark G. The Later Stuarts, 1660-1714. Oxford, Clarendon Press Publ., 1955. 479 p.

9. Clifford T.; Griffiths A.; Royalton-Kisch M. Gainsborough and Reynolds in the British Museum. London, The British Museum Publ., 1978. 92 p.

10. Colle E.; Mazzocca F. Il trionfo dellornato - Giocondo Albertolli (1742-1839). Cinisello Balsamo, Silvana Publ., 2005. 253 p. (in Italian).

11. Dukelskaya L. A.; Renne E. P. The Hermitage Catalogue of Western European Painting. British Painting, Sixteenth to Nineteenth Centuries. Moscow — and Florence, Giunti Publ., 1990. 550 p.

12. Furtwängler A. Die Antiken Gemmen. Geschichte der Steinschneidekunst im klassischen Altertum, 2 vols. Amsterdam — Osnabrück, Hakkert Verlag Publ., 1964-1965 (in German).

13. Grego J. Rowlandson the Caricaturist - A Selection of His Works, with Anecdotes, Descriptions of his Famous Caricatures and a Sketch of His Time, Life and Contemporaries. London, J. W. Bouton Publ., 1880. 414 p.

14. Guthrie N. The Material Culture of the Jacobites. Cambridge, Cambridge University Press Publ., 2013. 284 p.

15. Hallett M. Reynolds - Portraiture in Action. New Haven - London, Yale University Press Publ., 2014. 488 p.

16. Haskell F.; Penny N. Taste and the Antique - The Lure of Classical Sculpture, 1500-1900. New Haven - London, Yale University Press Publ., 1982. 376 p.

17. Herrmann H. J. Pier Jacopo Alari Bonacolsi genannt Antico. Jahrbuch des Kunsthistorischen Sammlungen der Allerhöchsten Kaiserhauses, 1909-1910, no. 28, pp. 210-288 (in German).

18. Herrmann L. The Drawings of Sir Joshua Reynolds in the Herschel Album. The Burlington Magazine, 1968, vol. CX, no. 789, pp. 650-658.

19. Ingamells J.; Edgcumbe J. (eds.). The Letters of Sir Joshua Reynolds. New Haven - London, Yale University Press Publ., 2000. 290 p.

20. Kurz O. Huius nympha Loci. The Journal of the Warburg and Courtauld Institutes, 1953, vol. 16, pp. $171-177$.

21. Leslie C. R.; Taylor T. Life and Times of Sir Joshua Reynolds, 2 vols. London, Murray Publ., 1865.

22. Lexicon Iconographicum Mythologiae Classicae (LIMC). Zürich — München, Artemis Verlag Publ., 1981-1999.

23. Loubat J. F. The Medallic History of the United States of America. 1776-1876. New York, J. F. Loubat Publ., 1878. 380 p.

24. Major E. Madam Britannia: Women, Church and Nation, 1712-1812. Oxford, Oxford University Press Publ., 2012. 384 p.

25. Mannings D. Sir Joshua Reynolds - A Complete catalogue of his Paintings. New Haven — London, Yale University Press Publ., 2000, 1264 p.

26. Mansuelli G. A. Galleria degli Uffizi. Le sculture. Parte I. Rome, Istituto Poligrafico dello Stato Publ., 1958, pp. 9697 (in Italian).

27. McPhee C. C. (ed.). Infinite Jest: Caricature and Satire, from Leonardo to Levine. New York, Metropolitan Museum of Art Publ., 2011. 224 p.

28. Mead R. A Mechanical Account of Poisons in Several Essays. London, J. Brindley Publ., 1745. 319 p.

29. Merriman M. P. Giuseppe Maria Crespi. Milan, Rizzoli Publ., 1980. 576 p.

30. Millar O. Zoffany and his Tribuna. London - New York, The Paul Mellon Foundation for British Art, Routledge and Kegan Paul and Pantheon Books Publ., 1966. 48 p.

31. Müller A. Framing Childhood in Eighteenth-Century English Periodicals and Prints, 1689-1789. Farnham, Ashgate Publ., 2009. 276 p.

32. Newman J. 'Reynolds and Hone: “The Conjuror” Unmasked'. Reynolds, exhibition catalogue, Royal Academy of Arts. London, Weidenfeld and Nicolson Publ., 1986, pp. 344-354.

33. Northcote J. The Life of Sir Joshua Reynolds. London, Henry Colburn Publ., 1818. 371 p.

34. Olson L. C. Benjamin Franklin's Vision of American Community. A Study in Rhetorical Iconology. Columbia, University of South Carolina Press Publ., 2004. 300 p.

35. Penny N. (ed.). Reynolds, exhibition catalogue, Royal Academy of Arts. London, Weidenfeld and Nicolson Publ., 1986. 408 p.

36. Perini Folesani G. Sir Joshua Reynolds in Italia (1750-1752): passaggio in Toscana: il taccuino 201 a 10 del British Museum. Florence, Olschki Publ., 2012. 512 p. (in Italian). 
37. Postle M. Sir Joshua Reynolds - the Subject Pictures. Cambridge, Cambridge University Press Publ, 1995. 396 p.

38. Reynolds J. Discourses. New Haven — London, Yale University Press Publ., 1981. 384 p.

39. Ricci G. Architettura in fiore. Reviving the Renaissance - the Use and Abuse of the Past in Nineteenth-Century Art and Italian Art and Decoration. Cambridge, Cambridge University Press Publ., 1997, pp. 63-94.

40. Schiff G. Henry Fuseli 1741-1825. London, Tate Gallery Publ., 1975. 144 p.

41. Smiles S. (ed.). Sir Joshua Reynolds - the Acquisition of Genius. Bristol, Sansom \& Co Publ., 2009. 208 p.

42. Spinola G. Il Museo Pio Clementino, vol. 3. Citta del Vaticano, Musei Vaticani Publ., 2004. 488 p. (in Italian).

43. Stuart Poole R. A Catalogue of the Greek Coins in the British Museum. Italy. London, Longmans Publ., 1873. 432 p.

44. Waldstreicher D. A Companion to Benjamin Franklin. Chichester, Oxford - Malden, Wiley-Blackwell Publ., 2011. $543 \mathrm{p}$.

45. Webster M. Johann Zoffany. New Haven — London, Yale University Press Publ., 2011. 416 p.

46. Wendorf R. Sir Joshua Reynolds - the Painter in Society. Cambridge, Mass., Harvard University Press Publ., 1996. $323 \mathrm{p}$.

47. Whittingham C. P., et al. Dictionary of Polite Literature, or, Fabulous History of the Heathen Gods and Illustrious Heroes, 2 vols. London, Scatcherd and Letterman Publ., 1804 (unpaginated).

48. Williams B. The Whig Supremacy. 1714-1760. Oxford, Clarendon Press Publ., 1965. 464 p.

49. Wills G. Washington’s Citizen Virtue: Greenough and Houdon, Critical Inquiry, 1984, no. 10, vol. 3, p. $420-441$.

50. Wright C. Poussin. Paintings. A Catalogue Raisonné. London, Alpine Fine Arts Publ., 1984. 304 p. 